\title{
PENGARUH PENERAPAN HUKUMAN TERHADAP KEMANDIRIAN SISWA
}

\author{
Jerobeam A. Selan ${ }^{1}$ \\ 1) SMK Negeri 1 Soe, Nusa Tenggara Timur, Indonesia \\ E-mail: yerobeamselan@yahoo.com
}

\begin{abstract}
Abstrak. Siswa adalah subjek yang belajar atau siswa disebut pelajar. Pelajaran di berikan kepada siswa yang sedang mengikuti proses pendidikan. Siswa dalam arti luas adalah setiap orang yang terkait dengan proses pendidikan sepanjang hayat sedangkan siswa dalam arti sempit adalah anak yang belajar di sekolah. Dikatakan pelajar karena mereka mengikuti pembelajaran dalam konteks pendidikan di sekolah, intinya bahwa hakekat seorang pelajar adalah belajar dan menuntut ilmu. Berdasarkan gambaran di atas dapat diketahuii bahwa kemandirian siswa adalah suatu sikap dimana seorang siswa atau subjek yang belajar mengembangkan diri dengan melalui jalur dan jenjang pendidikan yang betujuan untuk membentuk kepribadian seseorang untuk dapat berdiri sendiri.
\end{abstract}

Kata kunci: Penerapan Hukuman; Kemandirian Siswa

\section{PENDAHULUAN}

Pendidikan merupakan suatu pembentukan dan pengembangan kepribadian manusia secara menyeluruh,yakni pembentukan dan pengembangan potensi yang ada pada diri manusia.Dalam proses pendidikan harus menekankan pada pengembangan pengetahuan (kognitif),juga di arahkan pada pengembangan kemampuan untuk dapat melaksanakan sesuatu(psikomotor),serta di arahkan pada pengembangan sikap mental dan kepribadian sesuai dengan nilai-nilai di masyarakat(afektif).

Untuk mencapai tujuan pendidikan nasional maka diperlukan penyelenggaraan pendidikan yang sistimatik dengan sistem terbuka dan multimakna.selain itu pula di perlukan penegakan prinsip-prinsip dalam penyelenggarakan pendidkan artinya : Pendidikan dilaksanakan sebagai suatu pembuyaan dan pemberdayaan siswa yang berlangsung sepanjang hayat. Pendidikan diselenggarakan dengan memberikan keteladanan, membangun kemauan dan mengembangkan kreativitas siswa dalam proses pembelajaran.

Salah satu persyaratan agar proses penyelenggaran pendidikan dapat berlangsung secara efektif maka penegakan kedisiplinan siswa baik dalam kehadiran maupun keikutsertaannya didalam proses pendidikan.dalam menghadapi fenomena yaitu penerapan hukuman yang sering terjadi di sekolah,maka di perlukan pembudayaan hidup disiplin pada diri siswa.

Sebagai seorang pendidik tentunya sudah terbiasa menemui para siswa yang melanggar tata tertib,berperilaku menyimpang,mengganggu kegitan pembelajaran dan perilakuperilaku sejenis.tentunya terhadap siswa yang berperilaku demikian sebagai seorang pendidik tentunya tidak akan tinggak diam.perlu adanya punsment atau hukuman bagi siswa yang berperilaku negatif.sering dalam menerapkan hukuman guru terprovokasi menerapkan hukuman badaniah guna menghentikan perilaku negatif siswa.tidak jarang dalam menerapkan hukuman badaniah yang di lakukan gurucenderung berlebihan,bahkan dalam kasus tertentu hukuman badaniah yang di lakukan oleh guru berakhir di meja hijau.

Saat ini hukuman badaniah yang berlebihan dapat di kategorikan sebagai malpraktik yang di lakukan oleh guru.guru di tuntut menghindari pemberian hukuman badaniah untuk mengatasi perilaku negatif siswa.guru di harapkan menggunakan cara yang bersifat mendidik dalam menerapkan hukumn kepada siswa.pada kenyataannya sulit di hindari untuk tidak menerapkan hukuman kepada siswa.pada kenyataannya sulit di hindari untuk tidak menerapkan hukuman badaniah kepada siswa yang cenderung berperilaku negatif secara terus menerus dan dapat membahayakan bagi siswa lainnya.posisi dilematis semacam inilah yang tampaknya perlu di cermati agar kasus-kasus tindak kekerasan yang di lakukan kepada siswa dalam konteks penerapan hukuman tidak terjadi lagi.

Siswa adalah manusia yang memiliki kemampuan,kebiasaan,keinginan serta kecenderungan yang kompleks pada diri nya.maka sangat mudah di pahami jika di antara siswa melakukan tingkah laku yang menyimpang dari tingkah laku kedisiplinan yang di tuntut.

Menghadapi fenonmena yang sering terjadi,siswa $\mathrm{di}$ sekolah di angggap sebagai pengisi waktu saja.siswa yang berpendapat demikian akan menjadi penghalangdalam kemajuan belajar.untuk mengatasi kenakalan di sekolah adalah menjadi tugasguru atau pendidik.Pendidik di tuntut untuk dapat mencegah dan berupaya untuk dapat menumbuhkan kedisiplinan belajar siswa,agar siswa mempunyai tingkat kedisiplinan belajar yang tinggi di sekolah.Menghadapi siswa yang melanggar tata tertib dan 
kewajiban serta tugas yang diberikan, maka mereka akan dikenakan hukuman atau sanksi. Hukuman di sekolah di buat bukan sebagai pembalasan, tetepi dibuat untuk memperbaiki perilaku anak-anak dari kesalahan yang dilakukannya.

Dalam upaya mengubah tingkah laku agar siswa tidak berkelajutan bertingkah laku yang menyimpang, guru atau pendidik di tuntut untuk dapat mencegah atau berupaya untuk menumbuhkan kedisiplinan belajar pada diri siswa agar siswa punyan tingkat disiplin yang belajar yang tinggi di sekolah.seorang pendidik atau guru seringkali menggunakan dua model upaya pengubahan tingkah laku dengan berbentuk penerapan hukuman mempermalukan atau menumbuhkan rasa malu.

Berdasarkan dua model pengubahan tingkah laku serinkali seorang pendidik lebih memilih menerapkan hukuman terhadap siswa.suatu hukumah fisik belun tentu menjadi cara yang efektif untuk merubah perilaku siswa tetapi sebaliknya akan menyebapkan penyimpangan perilaku dari siswa semakin besar dan berlanjut kesalahan yang pada akhirnya menyebapkan tingkat kemandirian siswa menurun. Hal inilah yang mendorong penulis untuk mengadakan penelitian dengan "Pengaruh Penerapan Hukuman Guru Terhadap Kemandirian siswa Kelas X Smk Negeri 1 Soe".

\section{METODE}

Metode penelitian yang digunakan adalah metode penelitian deskriptif kuantitatif. Teknik yang digunakan untukpengumpulan data dalam penelitian adalah angket sebagai teknik utama sedangkan teknik-teknik yang lain hanya sebagai pelengkap dianataranya wawancara dan observasi, sementara teknik analisis data yang digunakan dalam penelitian ini adalah korelasi regresi jamak.

\section{HASIL DAN PEMBAHASAN}

TABEL 1

PENGARUH PENERAPAN HUKUMAN GURU TERHADAP KEMANDIRIAN SISWA

\begin{tabular}{|l|lc|cc|}
\hline $\begin{array}{c}\text { Penerapan } \\
\text { hukuman guru } \\
\text { terhadap } \\
\text { kemandirian siswa }\end{array}$ & Guru yang otoriter & \multicolumn{2}{|c|}{$\begin{array}{c}\text { Guru yang tidak } \\
\text { otoriter }\end{array}$} \\
\hline Guru yang otoriter & A. & \multicolumn{2}{|c|}{ B. } & 2895 \\
\hline $\begin{array}{l}\text { Guru yang tidak } \\
\text { otoriter }\end{array}$ & C. 1773 & \multicolumn{2}{|c|}{ D. } & 540 \\
\hline & \multicolumn{2}{|c|}{$\mathrm{A}+\mathrm{C}$} & \multicolumn{2}{c|}{$\mathrm{B}+\mathrm{D}$} \\
\hline Jumlah & \multicolumn{2}{|c|}{9004} & \multicolumn{2}{|c|}{3435} \\
\hline
\end{tabular}

Data tersebut dipindahkan kedalam rumus yulis ' $Q$ sehingga cara menghitungnya adalah:

$$
\begin{aligned}
& \mathrm{Q} \times \mathrm{Y}=\frac{(B \times C)-(C \times D)}{(B \times C)-(A \times D)} \\
& \mathrm{Q} \times \mathrm{Y}=0,13588
\end{aligned}
$$

Hukuman adalah fonis terhadap seseorang yang di anggap bersalah [1]. Dalam kehidupan masyarakat secara umum metode yang paling sering di gunakan untuk mendisipilkan seseorang adalah dengan pemberian hukuman pembentukan diri merupakan suatu proses yang harus di mulai sejak masa kanak-kanak.

Sebagian besar guru dalam mendidik siswa selalu menekankan disiplin yang tinggi, namun kerugiannya adalah disiplin yang tercipta merupakan disiplin jangka pendek artinya siswa hanya menurutinya sesaat sehingga tidak tercipta pada diri mereka hal ini di sebabkan karena anak lebih banyak mengingat hal-hal; negetif yang tidak boleh dilakukan dampak lain dari penggunaan adalah perasaan tidak nyaman pada anak karena harus menanggung hukuman yang ditetapkan [2].

Disiplin adalah proses pelatihan pikiran dan karakter yang meningkatkan kemampuan untuk mengendalikan diri sendiri dan m,enumbuhkan ketaatan atau kepatuhan terhadap tata tertib atau nilai tertentu. Tujuan utama adalah memberitahu dan menanamkan pengertian dalam diri anak tentang perilaku yang baik dan buruk. Dalam disiplin ada tiga unsur yang penting yaitu : hukuman atau peraturan yang berfungsi pedoman, penilaian, sanksi atau hukuman bagi pelanggaran peraturan dan hadiah perilaku atau usaha yang baik [3].

\section{Kemandirian siswa}

Kemandirian merupakan aspek kepribadian yang di singgung oleh para ahli psikologi dengan istilah dan definisi yang berbeda-beda.

Kemandirian berasal dari kata mandiri yang berarti berdiri sendiri. Kemandirian dalam arti psikologi adalah keadaan seseorang yang mampu memutuskan atau mengerjakan sesuatu tanpa bantuan orang lain. Kemampuan tersebut hanya mampu dimiliki jika seseorang berkemampuan untuk memikirkan dengan seksama tentang apa yang akan di kerjakan atau di putuskannya baik dari segi manfaat maupun keuntungannya [4].

Mandiri adalah kemampuan seseorang untuk mewujudkan kenginan dan kebutuhan hidupnya dengan kekuatan sendiri [5]. Kemandirian dengan istilah kebebasan dan menyatakannya sebagaoi salah satu tugas perkembangannya yang penting bagi remaja.

\section{Penerapan hukuman}

Faktor-faktor penyebab penerapan hukuman dalam dunia pendidikan adalah dari faktor guru itu sendiri,dari siswa, dari keluarga dan dari lingkungan. Sementara faktor yang mempengaruhi kemandirian siswa adalah faktor internal yang melipti emosi dan intelektual serta faktor eksternal yang meliputi lingkungan,karakteristik sosial, stimulasi, pola asuh serta cinta dan kasih sayang.

Kegiatan belajar mengajar merupakan kegiatan inti sekolah yang wajib di ikuti sekolah atau di laksanakan oleh dua komponen penting din sekolah yaitu guru dan siswa.kedua komponen ini tidak dapat di pisahkan karena memegang peranan yang cukup penting.dalam belajar siswa di tuntut atau di bimbing oleh gurumempunyai peranan sebagai pengolah dan penyaji pesan.pesan yang di maksut adalah bahan atau materi yang di olah atau di susun oleh gurusebelum di sajikan kepada siswa.dalam mengolah dan 
menyajikan pesan terkadang guru menngunakan berbagai cara untuk menghadapi watak dan tingkah laku siswa yang berbeda-beda.salah satu cara yang masih di gunakan dalam proses kegiatan belajar mengajar di kelas adalah menerapkan hukuman.penerapan hukuman yang di lakukan oleh gurudi dasarkan atas berbagai faktor di antaranya adalah kurangnya perhatian dari siswa ketika mengikuti proses belajar di kelas.

Hal lain yang mendorong guru menerapkan hukuman adalah ketika memberikan pekerjaan rumah siswa akan merasa santai dan tidak mengerjakan tugas tersebut.hal ini mendorong siswa menjadi objek emosional guru. Karena guru yang memiliki tingkat emosional yang tinngi tidak akan bertanya dan memberikan kesempatan kedua kali kepada siswa namun yang ada adalah penerapan hukuman yang berakibat siswa menjadi malas mengikuti pelajaran di kelas.

Hukuman yang mendidik adalah hukuman yang menyadarkan pihak yang bersalah dalam hal ini siswa, bahwa hal yang baru saja terjadi hendaknya tidak diulangi karena hal tersebut tidak disetujui guru. Penerapan hukuman harus dipandang sebagai bentuk pertanggung jawaban atas perbuatan yang melangggar batasan yang di tetapkan.

Pengaruh penerapan hukuman dan kemandirian siswa terlihat pada bagaimana guru menahan diri untuk tidak menerapkan hukuman terhadap siswa, karena hukuman yang dilakukan akan menjadi kesan negatif dalam kemandirian siswa. Sekecil apapun dampak yang timbul terhadap praktek penetapan hukuman dalam pendidikan, tetap saja adalah suatu kesalahan. Sekolah seharusnya menjadi tempat bagi siswa untuk mandiri. Namun, disaat penerapan hukuman terjadi disekolah, maka sekolah justru mematikan kemndirian siswa.

\section{SIMPULAN DAN SARAN}

\section{SIMPULAN}

Penerapan hukuman guru merupakan suatu sikap atau tindakan yang menimbulkan pengaruh-pengaruh negatif pada kemandirian siswa.hubungan saling pengaruh ini memiliki hubungan timbal balik yang saling berpengaruh yaitu bila penerapan hukuman meningkat maka kemandirian siswa akan semakin menurun,sebaliknya bila penerapan hukuman menurun maka tingkat kemandirian siswa meningkat.

Selain Hubungan saling pengaruh di atas penerapan hukuman guru dapat menimbulkan berbagai dampak di antaranya pengaruh pada perilaku,pengaruh pada sikap serta berpengaruh terhasap kemandirian siswa.penerapan hukuman guru terhadap siswa bukan saja terjadi di kelas tetapi terjadi juga di luar kelas dan bahkan pada proses pendidikan secara menyeluruh.penerapan hukuman guru kadsang di tiru oleh siswa sehingga terjadi pewarisan sikap yang kurang terpuji.

Terlepas dari keluarga dan masyarakat guruy adalah pribadi yang menentukan jaya atau runtuhnya semua bangsa dan peradaban manusia.di tangannya seorang anak yang tidak tahu apa-apa bisa berubah menjadi jenius,hal ini di lakukan melalui pembentukan sikapperilaku agar ke depan menjadi siswa atau anak yang mandiri.namun tak semua guru mampu menjadi pribadi yang mampu di tiru.sangat di sayangkan apabila dalam mendidik siswa guru menerapkan kekuasaan yang berdampak pada psikologi siswa.oleh karena itu untuk menjadi siswa yang mandiri,percaya diri maupun berinisiatif,serta mengatasi masalah maka guru di tuntut untuk mampu menjadi panutan bagi siswa dalam proses mencapai kemandirian tersebut.

\section{SARAN}

Penerapan hukuman guru memiliki pengaruh yang cukup signifikan terhadap kemandirian siswa, untuk itu sebaiknya:

1. Penerpan hukuman guru terhadap siswa sebaiknya dikurangi.

2. Siswa sebaiknya membentuk diri sendiri tanpa melihat pengaruh dari luar, sehingga terlihat menjadi siswa mandiri.

\section{DAFTAR PUSTAKA}

[1] Poerwadarminta, W.J.S. 1991. Kamus Umum Bahasa Indonesia. Jakarta: Balai Pustaka.

[2] Ruscue. 1996. Pengantar filsafat hukum. Penerbit rineka cipta. Jakarta

[3] Leman, Martin. 2000. Perkembangan mental dari bayi hingga dewasa [Online]. Tersedia: http://leman.or.id/anakku/daribayi.html [8 Februari 2011]

[4] Basri, Hasan. 2000. Remaja Berkualitas (Problematika Remaja dan Solusinya). Yogyakarta: Pustaka Pelajar.

[5] Gea, A.A. 2002. Relasi dengan Diri Sendiri. Jakarta: Elex Media Komputindo. 